Cities through the Looking Glass 



\section{Cities through the Looking Glass}

Essays on the History and Archaeology of Biblical Urbanism

Edited by

RAMI ARAV

Winona Lake, Indiana

EISENBRAUNS

2008 


\section{Dedicated to the memory \\ of \\ Clifton Brooks Batchelder}

(c) Copyright 2008 by Eisenbrauns.

All rights reserved.

Printed in the United States of America.

www.eisenbrauns.com

\section{Library of Congress Cataloging-in-Publication Data}

Cities through the looking glass : essays on the history and archaeology of Biblical urbanism / edited by Rami Arav.

p. $\mathrm{cm}$.

Includes bibliographical references and index.

ISBN-13: 978-1-57506-142-9 (hardback : alk. paper)

1. Cities and towns-Biblical teaching. 2. Cities and towns, Ancient-Middle East. 3. Urbanization-Middle East.

4. Bible. O.T.-Antiquities. 5. Middle East-Antiquities.

I. Arav, Rami.

BS680.C5C58 2007

$220.8^{\prime} 30776-\mathrm{dc} 22$

The paper used in this publication meets the minimum requirements of the American National Standard for Information Sciences-Permanence of Paper for Printed Library Materials, ANSI Z39.48-1984. @ ${ }^{\mathrm{TM}}$ 